\title{
Research on the Service Design Strategy and Practice of Red Cultural Tourism from the Perspective of Rural Revitalization
}

\author{
Pengfei Jing ${ }^{1, *}$, Lina $\mathrm{He}^{1,}$, Ruibo Song ${ }^{1}$ \\ ${ }^{1}$ School of Art Design, Shandong Youth University of Political Science \\ "Corresponding author. Email: jpfdsj@126.com
}

\begin{abstract}
Under the background of the inheritance of red culture advocated by the state, this paper analyzes the difficulties of the current red culture tourism and conducts practical research and in-depth analysis in Daigu Town. In order to better inherit the red culture and help the rural revitalization, this paper puts forward the service design strategy of rural red culture tourism, carries out the design practice, and provides new ideas for the study of red culture and rural tourism.
\end{abstract}

Keywords: Service design strategy, red cultural tourism, rural revitalization.

\section{INTRODUCTION}

Red culture is an important spiritual link connecting the past, present and future. Based on the analysis of the difficulties faced by the current red culture tourism, this paper makes a case study of Daigu town by using the thinking mode, process, tools and methods of service design. The service design strategy of rural red culture tourism is put forward, and the design practice is carried out at the same time. The purpose is to meet the new needs of users' tourism, inherit red culture and help rural revitalization

\section{BACKGROUND}

Since the 18th National Congress of the Communist Party of China (CPC), the CPC Central Committee has made solving problems related to agriculture, rural areas and farmers a priority in its work. Rural revitalization is a systematic project involving economy, politics, culture, ecology and society. ${ }^{[1]}$ General Secretary Xi Jinping has also stressed that culture is the focus on rural revitalization. Rural areas are the key to building a moderately prosperous society in all respects, and culture is the key to implementing the rural revitalization strategy. According to the Opinions of the CPC Central Committee and The State Council on the Implementation of the Rural Revitalization Strategy, it is necessary to "base on the rural civilization, absorb the excellent achievements of urban civilization and foreign culture, creatively transform and develop on the basis of protecting and inheriting, and constantly enrich the connotation of The Times and the forms of expression".

Red culture has a unique power to enhance cognitive identity. Red culture refers to the advanced culture with Chinese characteristics created by Chinese Communists, advanced elements and the masses during the revolutionary War. It includes both material culture and non-material culture, which contains rich revolutionary spirit and heavy historical and cultural connotation. The spiritual core of red culture are red spirit, which contains all kinds of spiritual forms reflecting socialist and communist value goals, embodies the general nature of national spirit, and is the national spirit and the spirit of the times for contemporary China. ${ }^{[2]}$

Red culture is also a recent research hotspot in the field of design, especially during the celebration of the 100th anniversary of the founding of the Communist Party of China. In 2018, the General Offices of the CPC Central Committee and The State Council issued the Opinions on the Implementation of the Revolutionary Cultural Relics Protection and Utilization Project (20182022), which clearly pointed out that a batch of revolutionary cultural propaganda and cultural creation products should be developed. At present, there are some prominent problems in the design of red culture, such as being intentionally useless, useful without beauty, and beautiful without anything else. There are many problems such as inflexible use of red cultural 
elements, lack of aesthetic feeling, poor function, excessive similarity of design results and creative points. The form of red culture tourism is too single and the users' pertinence is not strong. In particular, the outbreak of the epidemic has posed more challenges to the development of red culture tourism. ${ }^{[3]}$ Therefore, in the context of the rural revitalization strategy, the service design thinking and methods should be used to give play to its overall characteristics, combine the red culture with tourism, gain insight into the needs of various users, design innovative red culture tourism methods, enhance the dissemination of red culture, and help the implementation and promotion of rural revitalization. Headings should always be followed by text.

\section{SERVICE DESIGN OVERVIEW}

Different from traditional design, service design is an interdisciplinary field. It is an integrated design based on product design, user experience design, interaction design, etc. Through the research on tangible and intangible touch points, it makes global thinking and creates value. Service design focuses on the overall solution of service system, which can integrate and utilize resources, improve user experience and service quality, and form a complete service system framework and business model. Service design can be user-centered and integrate strategies to form a complete system of innovative solutions.

In 1982 and 1984, G. Lynn Shostack published two papers "How to Design a Service" and "Designing Services that Deliver", in which he first proposed the idea of Designing Services. [4] In 1991, Professor Michael Ehrhoff of the International School of Design of the University of Applied Sciences in Cologne put forward "service design" for the first time in the field of design. Then "Engine", "IDEO" and other design companies began to carry out service system design practices. In recent years, service system design as a way of thinking and tool method has been paid more and more attention in China, the momentum of rapid development. ${ }^{[5]}$ With the development and subdivision of service industry, customer pay more and more attention to service quality and service experience, which also makes service design into everyone's vision. Service design, as a way to provide users with better service experience and achieve a win-win situation for all stakeholders, can play an important role in culture, tourism and other fields.

\section{CASES}

Daigu Town, Mengyin County, Shandong province is located in the hinterland of Yimeng Mountain area in the north of Linyi City. The town covers an area of 180 square kilometers and has 34 administrative villages.
Daigu town has a unique natural landscape, a unique "Daigu landform" geological wonders, known as "China multifunction township". Daigu Town is a revolutionary base area, with excellent red genes. The revolutionary period of the Dragon multifunction uprising, two northsouth defense battle, multifunction defense battle, Sanbao Mountain bloody battle and other famous battles occurred in The Dai Multifunction. After the founding of the People's Republic, Daigu Town in response to the country's "preparedness for famine for the people" calls, relying on dai Multifunction landform construction of the original Min Feng machinery factory, mold and mould field, Shandong province military bureau central hospital, white lawn military aircraft factory and other "three line" military bases. A large number of educated youth and excellent engineering and technical personnel gathered here, leaving a strong military culture. In 2016, Daigu Third-line military Industrial Park was awarded the title of "China's third-line military Industrial Cultural Park" by the State Administration of Science, Technology and Industry for National Defense. In 2019, it was awarded the honorary title of "Shandong Province Cares about the next generation education Base".

Although Daigu Town has many unique advantages, there are still some deficiencies in rural characteristics development, agricultural products promotion, ecological tourism, red culture communication and other aspects. Therefore, from the perspective of rural revitalization, we need to take red culture tourism as the entry point to discuss how to integrate red culture through service design. To output designs which can not only meet the needs of consumers, but also meet the demands of other stakeholders. It is of great significance to promote the red culture of Daigu, promote economic development and create a distinctive red culture tourism model.

\section{SERVICE DESIGN STRATEGY}

\subsection{Subdivide users and explore the needs of different users for red culture tourism}

The research on rural red cultural tourism needs to be carried out comprehensively and systematically, which contains the unique needs of different groups of people, and requires us to disperse target users, subdivide user categories, and combine the research on their stakeholders to gain insights into user needs. Use brainstorming, mind mapping, field research, user interviews and other methods to expand and analyze user groups, and subdivide users into various categories. At the same time, the potential core demands of each type of users are different, and there are a large number of stakeholders associated with their needs. On this basis, stakeholders can be analyzed to think about the needs of users and stakeholders together, sort out the relationship between them, and then get their needs. 
Only the targeted subdivision of users and mining their needs can effectively carry out the system construction and contact point performance of service design.

The core users of "Dai Ru Gu Shi" Immersive Red Culture Tourism Experience Design Project for schoolage children are defined as school-age children. Through user research on school-age children, we found that they have a strong interest in red culture, and their parents also hope to guide their children to establish a correct concept through the education of red culture. When analyzing the stakeholders of red culture education for school-age children, we found that red stories are very attractive to children, especially the process and plot. Therefore, the design project studied the children's parents and local villagers as the main stakeholders. Parents are responsible for the overall implementation of children's red tourism plan. Local villagers have the best understanding of the local red culture and are able to tell children about the red culture in detail by combining the oral stories of the older generation. To build the immersion of school-age children red cultural tourism experience system, through the way of red tourism, school-age children home long arrangements at the local villagers converted the home stay facility, through the life with the villagers, communication, visiting and teaching approaches, in complete journey at the same time, in-depth understanding and experience of local red culture.

\subsection{Build a system to show the design concept of red culture tourism through the service system}

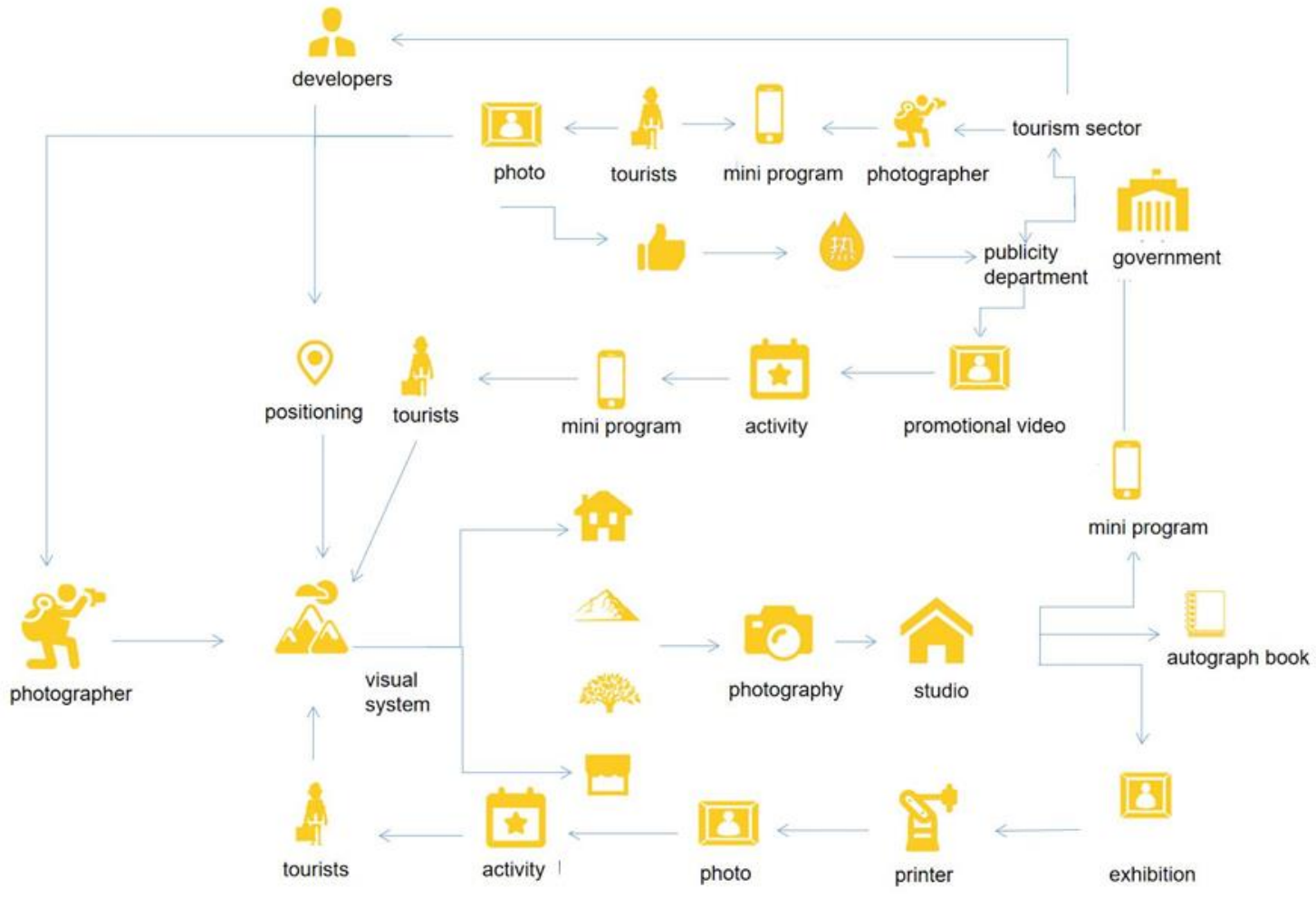

Figure 1 "Gu You" Red Culture Tourism Photography Service System Design

The study of rural red cultural tourism involves the needs of many parties and is relatively complex, so it is necessary to systematically analyze and sort out the solutions to the problems. Through constructing the service system, integrating multiple resources, clarifying the relationship between stakeholders and core users, and reflecting the operation of the system through the input and output of material flow, information flow, energy flow and capital flow. For the key link of the system running, through the output of the contact point, its function is realized to ensure the operation of the service system. With the help of the service system map tool, the service system composed of users, stakeholders, contact points and interaction behaviors is displayed, and the design concept of red cultural tourism is clearly displayed.

The project of "Gu You" Red Culture Tourism Photography Service System Design builds a photography service system with photography enthusiasts as the core users and red culture tourism as the characteristics. In addition to photographers, there are tourists, tourism departments, government propaganda departments, photography studios and other stakeholders in the system, who constitute the main body of the service system. The system also has multiple touch point designs such as "Gu You" travel photography APP, scenic spot self-help camera, photo exhibition hall. Photographers can upload a large 
number of photos taken during the travel to the APP. Users can browse the excellent works of professional photographers in the APP at any time, which can attract them to visit. Meanwhile, these photos can also be used and promoted by the publicity and tourism departments of the government. Through the positioning function in the multifunction APP, the geographic location of the photo can be marked, so as to create a bottom-up hot Internet celebrity tourism card landmark. Tourists can purchase professional photography services provided by local photography studios through the APP to take professional travelled photos. All photos taken through the multifunction APP can be printed in real time in the self-service camera of the scenic spot and stored in the photo exhibition hall. These photos will be uniformly collected by the scenic spot, combined with the local important folk customs, festivals held activities, regular exhibition.

\subsection{Integrate resources and expand the design category of touch points bearing red culture}

Through the in-depth analysis of the constructed service system, the subsystem functions and their mutual relations of the system are refined. Through the input and output of material flow, energy flow, information flow and capital flow, the main role of the contact point is clarified. In order to ensure the effective operation of the service system, it is necessary to integrate corresponding resources, expand the contact point design category bearing red culture, and conduct contact point positioning and design performance from the perspectives of visual image design, product design, display design, space design, cultural and creative design.

"Daigu Source Record" Red Culture System Design Project based on red tourism, led by the government to create a red brand on The multifunction, red travel APP, red cultural experience hall, red cultural and creative products integration. Through the user's travel process, the three are connected to form a complete closed loop. With the help of the red brand of Dai Gu Mountain, tree strong brand awareness, can integrate scattered resources, forming a resultant force. The Red Travel APP allows users to learn about The local customs, red culture and popular scenic spots of Daigu in advance. Combined with the specific travel of the Red Culture experience museum, users can deeply experience the local red culture. The design of red cultural and creative products can make red culture fill users' life scenes and deeply integrate red culture and users' life.

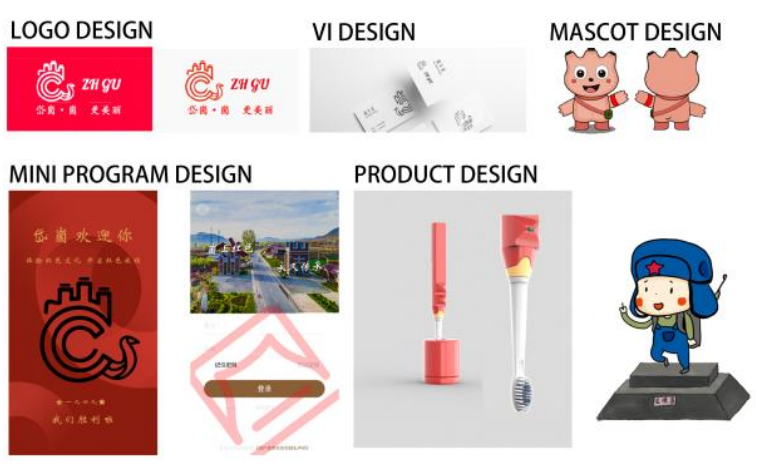

Figure 2 " Daigu Source Record" Red Culture System Design

\subsection{In accordance with the requirements of epidemic prevention and control, a new model of red culture tourism service should be established}

China is still at a critical stage of epidemic prevention and control, and travel restrictions cannot be fully lifted. But there is also a necessity to travel. Although the COVID-19 has changed people's lives, it has also created new ways of consumption, which has also raised new possibilities for tourism. Against the backdrop of the epidemic, a new mode of tourism service should be created by combining online experience with offline precision tourism, with surrounding tourist attractions and local consumption as the main channel.

The design project of "Guxiang" Red Culture Tourism Service System considered the special requirements of the epidemic for tourism, and proposed a new service mode. Led by the Government of Daigu Town, the online tourism platform of each scenic spot is set up. Local residents are the main participants to carry out live broadcast activities, and the red culture and tourism characteristics of local scenic spots are displayed through live broadcast. After consumers have a preliminary understanding of online experience, they can carry out in-depth offline tourism. Offline tourism takes local residents as tour guides, provides special services with consumers, and presents red culture, food culture and regional culture by means of transportation transfer, stay in homestay, scenic spot tour and other ways, combining with the main places of local folk museum, old teahouse and specialty museum. This mode can fully adapt to the special requirements of the epidemic, ensure the depth of experience, and provide the government with travel data when necessary, which is conducive to the traceability of the trip.

\section{CONCLUSION}

By exploring the combination of red culture and rural tourism, putting forward effective service design 
strategies and carrying out corresponding design practices, new ideas can be provided for the study of red culture and rural tourism, so as to meet the new tourism needs of users, inherit red culture and help rural revitalization.

\section{ACKNOWLEDGMENTS}

Key subjects of art and Science in Shandong Province.

First-class courses and applied courses of Shandong Youth University of Political Science.

\section{REFERENCES}

[1] Lu Bin. The necessity, dilemma and path of rural culture reconstruction from the perspective of rural revitalization [J]. Strives for realism, 2019 (02): 97-108+ 112 .

[2] Ding F Y. Red Culture: An effective Carrier to promote core values Education [N]. Guangming Daily,2013-11-09(011).

[3] Song S L, Luo X H. Research on problems and strategies of "red" cultural and creative product design [J]. Design art research,2018,8(06):116-122.

[4] Hu F, Li W Q. Defining "service design" [J]. Packaging engineering,2019,40(10):37-51.

[5] Xin X Y, Cao J Z. Positioning service design [J]. Packaging engineering,2018,39(18):43-49. 